\title{
The second slavery
}

A segunda escravidão

La segunda esclavitud

Le deuxième esclavage

Ricardo Salles [1]

\section{TOMICH, Dale. Pelo prisma da escravidão. Trabalho, Capital e Economia Mundial. São Paulo: Edusp, 2011. 248 p.}

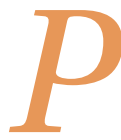
elo Prisma da Escravidão. Trabalho, Capital e Economia Mundial. This is the title of Dale Tomich's book, recently translated and published in Portuguese by Editora da Universidade de São Paulo. It is a collection of texts written by the author, who is also a professor of Sociology and History at the State University of New York at Binghamton. Tomich is well-known in Brazil and has been to the country numerous times. ${ }^{1} \mathrm{He}$ is also involved in several studies by Brazilian researchers, which brings him to the country often.

Pelo Prisma da Escravidão was released in English in $2004 .^{2}$ The book gathers articles published between 1987 and 1997 and is divided in three parts. The first is entitled "A Escravidão na Economia Mundial" ("Slavery in World Economy") and is subdivided in three chapters. In this review, I will focus on chapters one and three contained in the first part. These chapters provide a prospectus of the analysis that unfolds in the subsequent two parts of the work, "O Global no Local" ("The Global in the Local") and "Trabalho, Tempo e Resistência: Mudando os Termos da Comparação" ("Work, Time, and Resistance: Changing the Terms of Comparison") in which Tomich analyses the French, English, and Spanish Caribbean between the end of the $18^{\text {th }}$ century and the first half of the $19^{\text {th }}$ century.

The key concept that organizes the book in its entirety, and which is also the title of the third chapter, is that of second slavery. It a revised version of one of the chapters contained in the 1988 collective work Rethinking the 
Nineteenth Century: Movements and Contradictions. ${ }^{3}$ Tomich's argument is that modern slavery was not always the same between the $16^{\text {th }}$ and the $19^{\text {th }}$ centuries. At the turning of the $18^{\text {th }}$ to the $19^{\text {th }}$ century, a set of historical events and tendencies, especially the Industrial Revolution in England and Great Britain's international hegemony, led the global market towards profound reconfigurations. There was an increasing imbalance in the international prices of industrialized and agricultural products; an increase in the consumption of certain products, such as coffee and sugar, demanded by a growth in the population of workers and of the middle class in English and European cities; and a search for new raw materials, such as cotton. If this set of transformations affected certain colonial areas that relied on slavery, causing their decline, it also acted over other slavery areas almost in a contrary manner. In regions such as Cuba, the south of the United States, and Brazil, where slavery was initially not in the forefront, it "expanded on a massive scale in order to attend the increasing global demand for cotton, coffee and sugar" (p. 83). Slavery was remodeled as a

new constellation of political and economic forces [...] The systemic meaning and character of slavery were transformed (p. 87).

These emerging centers of slavery were increasingly more integrated and impelled by industrial production.

This 'second slavery' was developed not as a historical premise of productive capital, but with the presupposition of its existence as a condition for its reproduction (p. 87).

We are far from the view of a modern slavery exclusively restricted to a subordinate element of the historical process of primitive accumulation of capital. A type of slavery that was fated to disappearing, despite the survival and resistance initiatives promoted by dominant groups attached to it, in such a way that its history over the course of the $19^{\text {th }}$ century was the history of this Dantesque death announced beforehand. Antithesis "of the emergent forms of State, moral sensitivity and economic activity", slavery was "the negative pattern against which new forms of freedom defined themselves" (p. 81). Its abolition was inevitable. Even though almost one century elapsed between the slaves' revolution in Saint-Domingue in 1791 and the abolition in Brazil in 1888, and although several different national and regional paths were trailed along the way, its destiny was already laid out. For some, because of the advancement of moral forces; for others, due to the development of industrial production and capitalism.

Dale Tomich disavows this model. He shows how this second slavery was integrated to the development of industrial capitalism and the global market under British hegemony in the $19^{\text {th }}$ century. And, because of this,

${ }^{3}$ Francisco O. Ramirez (ed.), Rethinking the Nineteenth Century: Movements and Contradictions, Westport, Greenwood Press, 1988. 
even if contradictorily, the second slavery unfolded along with this development and not in spite of it. At this point, when outlining the objective of the chapter as that of drawing attention to the multifaceted character of slavery in the $19^{\text {th }}$ century, considering its integration with the development of capitalism, the author warns that he does not propose "to explain the causes of the slaves' emancipation, which remain diverse and conjunctural" (p. 82). Instead, he aims at drawing attention to the "formation and reformulation of slavery-based relations within the historical processes of global capitalist economy" (p. 82). Thus, even if

slavery was abolished in all quadrants of the hemisphere, the 'antislavery century' was, nevertheless, the pinnacle of its development (p. 82).

In the first chapter of the first part of the book, "Capitalismo, Escravidão e Economia Mundial" ("Capitalism, Slavery, and Global Economy"), the theoretical viewpoint that underlies the concept of second slavery, is exposed, complemented and explained further. Chronologically, this chapter, like the second, which I will not address here, was written in 1993, after the third chapter. ${ }^{4}$ However, from the theoretical point of view, the exposition and the book as a whole, it correctly appears as the first. This fact is not of lesser importance, and it reinforces a decisive point in the work in question, i.e. the centrality of what Tomich calls theoretical history.

With the purpose of opening his argumentation, he points the shortcomings of three great interpretive strands about modern slavery: those of the New Economic History, present in the works of John H. Conrad and John R.

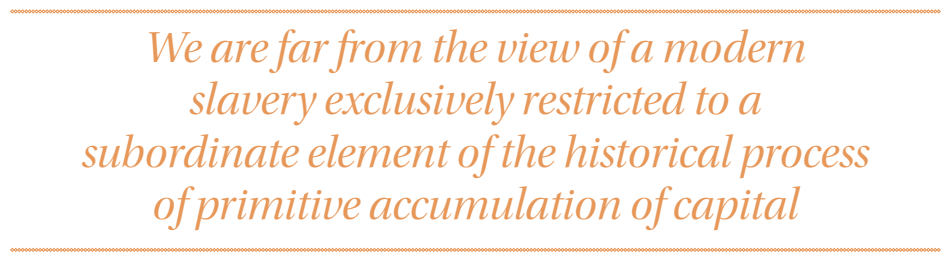

Meyer, and Robert W. Fogel and Stanley L. Engerman; Eugene Genovese's Marxist interpretation; and Immanuel Wallerstein's Modern World Systems. ${ }^{5}$ In summary and schematically, the New Economic History presumes the universal validity of economic categories, applicable both to capitalist and slavery-based economies, leaving questions concerning historical interpretation

${ }^{4}$ Dale Tomich, "World Market and American Slavery, Problems of Historical Method", in Manuel Ceda (ed.), Els espais del mercat, Valência, Diputació de Valencia, 1933. pp. 213-240.

${ }^{5}$ John H. Conrad \& John R. Meyer, The Economics of Slavery and Other Studies in Economic History, Chicago, Aldine, 1964; Robert W. Fogel \& Stanley L. Engerman, Time on the Cross. The Economics of American Slavery, Boston, Little Brown and Company, 1974, 2 v.; Eugene D. Genovese, The Political Economy of Slavery, Nova York, Random House, 1967; Immanuel Wallerstein, The Capitalist World-Economy, Nova York, Cambridge University Press, 1979. 
and the formation of social relations unanswered. In his turn, Genovese regards slavery and capitalism as incompatible systems, the latter more modern and the first more outdated, involving different moments of the historical evolutionary process. Finally, for Wallerstein, Modern World Systems, by encompassing work relations that are both salaried and coercive - among them, slavery - constitute a single empirical structure with multiple forms of work but losing sight of fundamental differences among different social relations of production.

At the end of this critical digression about the aforementioned authors, Tomich proposes a fundamental distinction between historical theory, "concerned with formulating appropriate theoretical categories for the comprehension of a historically distinct object of investigation", and theoretical history, "concerned with the use of these categories to reconstruct processes of historical development" (p. 37).

In the first case, it is how Marx proceeded in his Capital: he constructed a theoretical object, the capital, assigning its specificity "as a particular historical form of social relation of production, having work as its content" (p. 39, original italics). Although Marx addresses a particular historical time, referring to several places - such as England during the Industrial Revolution - and to concrete historical processes, as it happens in the case of his description of the process of original accumulation of capital, Marx concatenates his categories logically. This tension inherent to his method, used as criticism to universal categories of political economy, between his proposal of distinguishing the historicity and the relational character of these categories - capital and work - and the logical exposition of his own concepts is at the root of the mistaken interpretations about slavery that are criticized by Tomich. In one way or another, all of them treat capitalism and slavery as abstract and separate entities, imbued with essential attributes.

It is possible to affirm that the implication of these conceptions is that slavery ends up "out of place". Reduced to a historical contingency of the stage of original accumulation of capital, it is entirely subsumed to the logic of capitalism, thus losing its specificity and its history (as in the case of the perspectives of the New Economic History and the Modern World Systems). Or it displays traces of a system that served a function in the stage of original accumulation but which became increasingly anachronistic and incompatible with capitalism (Marxism).

At this point, upon assigning the unprecedented recrudescence of slavery forms exactly to the moment when the global market expands itself under Great Britain's hegemony, where the core of the Industrial Revolution was developed, the concept of second slavery shows its full force. Slavery is no longer regarded as an abstract entity that is always its own equal. Without being confused with capitalism in its configuration, they coexist in the same world, albeit in a complex and contradictory manner. From the point of view 
of theoretical history, capitalism and slavery are regarded as "specific forms of social production or trade" that are not understood

as autonomous units with their own history, but formed through their relation with a broader political and economic totality (p. 50).

A totality that directly affected the lives of masters, slaves, and their societies in general. This totality, of which the second slavery was a fundamental integrating and active part, and not only an appendix or a remainder of the colonial or Old Regime, was affected, in turn, by the actions and struggles of masters, slaves, and other social, political and cultural agents of American slavery societies. Both points cannot be ignored by historians, under the penalty of making lame history, reproducing or leaving untouched stereotypes and traditions about notions such as freedom, free work, liberalism, capitalism, and, of course, slavery.

If the proposed perspective is to be taken into consideration, it is necessary to rethink the meaning of slavery-related struggles in the context of the

\section{Slavery is no longer regarded as a self-same abstract entity}

second slavery, as well as their conditions and consequences. Such a difference among historical situations, as that experienced between the "first" and the second slavery, without mentioning the differences that are more specific to each particular context and conjuncture, cannot be completely understood without reference to the global scenario of the capitalist world economy and to the second slavery.

A final word on the elaboration and reception of the concept of second slavery, which has been more and more discussed by several historians in Brazil and abroad. ${ }^{6}$ As we have seen, it was originally elaborated in 1988 and it reappeared in the first English edition of the book in 2004. This reappearance

\footnotetext{
${ }^{6}$ See Christopher Schmidt-Nowara, Empire and Antislavery: Spain, Cuba and Puerto Rico, 1833 - 1874 , Pittsburgh, University of Pittsburgh Press, 1999; Rafael Marquese, Feitores do corpo, missionários da mente. Senhores, letrados e o controle dos escravos nas Américas, 1660-1860, São Paulo, Companhia das Letras, 2004; Ricardo Salles, E o Vale era o escravo - Vassouras, século XIX. Senhores e escravos no Coração do Império, Rio de Janeiro, Civilização Brasileira, 2008; Michael Zeuske, "Comparing or interlinking? Economic comparisons of early nineteenth-century slave systems in the Americas in historical perspective", in Enrico dal Lago \& Constantina Katsari (eds.), Slave Systems. Ancient and Modern, Cambridge, Cambridge University Press, 2008, p. 148-183; José A. Piqueras (ed.), Trabajo Libre y Coactivo en Sociedades de Plantación, Madri, Siglo XXI, 2009; Anthony Kaye, "The Second Slavery: Modernity in the Nineteenth-Century South and the Atlantic World", Jornal of Southern History, vol. 73, n. 3, August 2009, p. 627-50; Rafael Marquese, Márcia Berbel e Tâmis Parron, Escravidão e política. Brasil e Cuba, c.1790-1850, São Paulo, Hucitec, 2010; Tâmis Parron, A política da escravidão no Império do Brasil, 1826-1865, Rio de Janeiro, Civilização Brasileira, 2011; Robin Blackburn, The American Crucible. Slavery, Emancipation and Human Rights, Londres, Verso, 2011; Enrico Dal Lago, American Slavery, Atlantic Slavery, and Beyond. The U.S. "Peculiar Institution" in International Perspective, Boulder, Paradigm Publishers, 2012.
} 
was not entirely editorial. In 1988, at the heyday of the microhistory vogue, the linguistic turn, the methodological individualism, and everything else that, at the height of neoliberalism, promised to bury Marxism and other totalizing views of history, Tomich's text remained unnoticed. It seems that things are different now. Starting with neoliberalism, which, in addition to being reduced to a doctrine that fosters high finances, also has plunged the world in an unprecedented crisis in the last 70 years.

In the field of historiography, the road has been cleared of dense descriptions of what is private, routine and minute and preceded by quick contextual glimpses added to two or three superficial generalizations that allude to the necessity of broader, deeper and concrete analyses of historical objects. If these descriptions helped to overcome the old approach to the systems in question, relying on sociological, abstract and logical patterns, nowadays they are no longer sufficient. ${ }^{7}$ It is time, now, to seek analyses that turn to the connections, links and contradictions that compose these objects as structured totalities, at the same time produced and conditioned by human actions. This is what Tomich seeks with Pelo Prisma da Escravidão, indicating ways to get it done, and done well. 